\title{
Role of social media in retail network operations and marketing to enhance customer satisfaction
}

\author{
Usha Ramanathan*a, Nachiappan Subramanian ${ }^{\mathrm{b}}$, Guy Parrott ${ }^{\mathrm{c}}$ \\ ${ }^{a}$ Nottingham Trent University, Nottingham Business School, UK \\ *-corresponding author \\ ${ }^{\mathrm{b}}$ University of Nottingham, Ningbo, China \\ ${ }^{\mathrm{c}}$ University of Bedfordshire, Luton, UK
}

\begin{abstract}
Purpose: The technology evolution compels retail networks to introduce unique business models to retain customers and to gain a competitive advantage. Customer reviews available through social media need to be taken into account by retail networks to design a model with unique service operations and marketing approaches that will improve loyalty by adding value to customers. Furthermore, the relationship between customer satisfaction and customer spending behaviour is very weak and needs further investigation. Hence our study attempts to understand how retail network leverage the potential of social media reviews along with unique service operations to satisfy customers. The study analyses the nexus of: a brand, promotional offers, service operations; and their interaction through social media reviews on customer satisfaction levels.
\end{abstract}

Design/methodology/approach: We develop a conceptual model for the social media era. We combine the idea of loyalty-based and value based models of Chatterjee (2013). We employed a survey questionnaire method to elicit opinions of retail customer satisfaction based on social media reviews, service operations and marketing efforts. We derive measures of our model from existing literature and expert opinion.

Findings: Social media reviews dramatically impact upon customer satisfaction. Similarly our empirical analysis identifies the significant and positive role played by service operations in customer satisfaction levels. Interestingly we didn't find unequivocal support for brand satisfaction impacting on customer satisfaction. However, when promotions interact well with service operations, the level of customer satisfaction is significantly affected. Similarly we didn't observe a positive outcome when there is an interaction between promotion and social media reviews. After reading the reviews, some potential buyers make a visit to store before making final decisions and surprisingly, promotional effects do not change their mind set.

Practical implications: Research findings confirm the importance of social media reviews, marketing and interaction between promotion and service operations enabling retail networks to build loyalty and value based models. Based on customer behaviour, the study suggests a need to consider operational efficiencies when promoting sales; through careful planning, customer satisfaction and profitability levels can be increased. This sends a strong message to the retail network to defend their position within a very competitive business market. 
Originality/value: Our empirical evidence based on customer experience would be helpful for companies in integrating their operations and marketing efforts enabling them to convert different segment of customers such as 'free riders (higher satisfaction and low profitability)' and 'vulnerable customers (Low satisfaction and higher profitability)' into 'star customers (higher satisfaction and high profitability) '. Through a considered approach: combining social media reviews, marketing and operations, businesses will be better-placed to survive in the ultra-competitive social media-influenced era.

Keywords: Social media review, customer satisfaction, service operations, promotional sales

\section{Introduction}

The emergence and acceptance of social media as a significant component of daily lives in the majority of global population, has dramatically changed customers' buying patterns. This has acutely changed the buyer / seller dynamics in retail networks; where the preponderance of social media and e-commerce has provided contemporary buyers with a greater pallet of purchasing options to choose from. This drastically changes many retailers' and manufacturers' production, logistics and distribution planning. Additionally, customers' unpredictable buying behaviour affects the whole retail network in terms of excess inventory or shortage. This in turn, necessitated a greater interaction between operations and marketing functions within the retail network.

Marketing literature claims that store promotions and loyalty schemes are powerful enough to change customer buying behaviour (Divakar et al., 2005; Kopalle and Neslin, 2003). Although customers are attracted by the plethora of promotions and loyalty schemes, customers may not be ready to compromise the in-store service operations and feedback in shopping. Customers' satisfaction is also partly related to store facilities such as service quality, store attraction and availability of branded items (Martenson, 2007).

A greater understanding of service quality and its impact on customer satisfaction can help to increase effective operations in retail services (Ramanathan and Ramanathan, 2011). However, with the influence of social media, the concept of customer satisfaction cannot simply be measured at a single point, as customers' experiences are gained from several 'touch-points'. For example, measuring customer expectations before shopping and perceived satisfaction after shopping may help one to understand the reasons behind customers' buying intentions (Zhu et al., 2011). A further complication was suggested by Keiningham et al. (2014) that the relationship between customer satisfaction and customer spending behaviour is very weak and therefore, needs further investigation. 
In this digital era, customers make use of internet to preview retailers perusing their websites as well as popular third-party sites featuring retailers and their products. This behaviour represents an entirely different experience to shoppers who prior to the internet age, could only gain an insight by actually visiting the store! In the presence of social media, some businesses offer virtual tours of their retail outlets that can provide potential shoppers with guides to convenience features such as parking and opening hours; helping customers to make decisions to frequent certain shopping destinations. Some customers make use of the store websites to understand previous customer experiences by displaying their feedback as reviews that supports shopping decisions ("Retailing Today", 2013). Normally, negative reviews left by the customers discourage any future customers (Ramanathan el al., 2013). Social media reviews not only capture instant emotional experiences to guide shoppers, but also inform store managers. These social media reviews help managers to identify potential future problems and to identify optimal solutions to attract new customers, as well as retaining existing customers. Hence with the support of social media reviews, operations and marketing departments of a firm can work together to improve the customer experience and shopping satisfaction. Firms are still exploring guided ways to achieve both customer satisfaction and profitability (Keiningham et al., 2014). Increased understanding of the interaction of service operations and marketing efforts of firms represent a key requisite in the delivery of service quality, highlighted in customer feedback; preparing the ground for future product and service developments.

Shoppers access social media platforms to routinely share their views on store choice, brand choice and their experiences with friends and relatives; thereby influencing other peers destination, product and brand choices. Such intentions and behaviours are also influenced by other notable factors such as promotional offers and gift vouchers during the shopping period. Some customers are compelled to visit a particular shop in a specific period to avoid gift voucher expiry. It is invidious to predict if this trend will persist, but currently customers are keen to embrace price-related promotions (Ramanathan, 2012; Divakar et al, 2005). This represents a significant challenge for store managers as they plan promotions and factor in forecasted stock replenishment requirements (Fernie, 1995; Ramanathan and Muyldermans, 2010). Ever-changing customer purchase behaviour represents a significant challenge for store mangers' on what they need to focus on. For example, it is hard to pinpoint the key ingredients of customer satisfaction from the social media reviews, brand satisfaction and store operations. 
With the addition of promotions and related marketing and brand activity, the complexity of this challenge is multiplied.

In this study, we try to understand the role of several operations (such as store service quality and store convenience), marketing (such as brand and price promotions) and social media reviews (shop reviews and product reviews) on customers' satisfaction levels. We develop a conceptual model using the idea of loyalty and value-based models proposed by Chatterjee (2013). To validate the model, we have collected retail customers' views on weekly grocery shopping experiences with respect to various features such as: loyalty schemes, convenience and price. We conducted this survey in the South East region of the UK. Based on the survey data we develop a structural equation model to verify the impact of elements of social media reviews, operations and marketing functions role on customer satisfaction. We also test the moderating role of sales promotions in this particular relationship. The results of the analysis clearly specify the moderating role of different promotions in the relationship between service operations and customer satisfaction, but not in the relationship between social media reviews and customer satisfaction. In the next stage we conducted a multi-group analysis based on age and income of customers, which do not show any significant changes in these relationships. Our research aims to prompt the managers how to plan considering promotional sales along with operational efficiencies and recommends guided attempts to improve satisfaction and profitability. To achieve this objective, we have conducted background research on social media assessing and its impact on retail operations and customer shopping satisfaction.

Our empirical evidence would be helpful for companies to devise its operations and marketing efforts to achieve the target of converting different segment of customers classified based on level of satisfaction and profitability such as 'free riders (higher satisfaction and low profitability)' and 'vulnerable customers (Low satisfaction and higher profitability)' into 'star customers (higher satisfaction and high profitability)'.

The remainder of the paper is organised as follows. The next two sections detail the background of the study and reviews previous studies with respect to social media, sales promotion, marketing, retail service operations and customer satisfaction. Section 3 explains the conceptual model and research hypothesis. Section 4 describes the method adopted for the study and the data. Section 5 discusses the outcome of the study along with managerial implications; the final section summarises the findings, contributions together with future research directions. 


\section{Background study}

In the past decade, the UK retail sector has shown a high inclination towards two main business models namely: a loyalty-based network value model and a perceived value-based model (Chatterjee, 2013). Currently leading UK retailers, such as Sainsbury's and Tesco, are heavily dependent on those network value models; for example, store cards and club cards are in place to increase regular sales. However, other smaller retailers like Aldi and Lidl support their sales employing a value-based model like stocking customers' favourite items at a low price. In both these cases, the companies are able to achieve expected sales. But, the fluctuation of sales is really not answered through normal sales-demand analysis. To understand the demand specific to any sales, the company needs a detailed analysis of underlying factors of demand (Ramanathan, 2013); especially in the context of retail sector, promotions and social media reviews potentially heavily affect sales (Nair and Kamboj, 2014).

\subsection{Impact of Social media review on retail sales}

Social media effects are currently an engaging area for researchers both in marketing, tourism, retailing and service fields. Marketing and tourism literature clearly elucidate the link between information of customer experience through social media and the level of customer satisfaction. This is currently being used as a feeder information set for future customers (Xiang, and Gretzel, 2010; Munar and Jacobsen, 2014). Some studies have used email information to understand service quality (Matzler et al. 2005). Although online customer ratings, social media sites (such as ebay and bizrate), have been used for performance measurement in the service industry for the past three decades, it is not entirely clear how social media can change planning and improve performance in the retail sector (Ramanathan and Ramanathan 2011; 2013).

As social media increasingly plays a major role in many businesses, success or failure of the businesses is based on the analysis of customer feedback and related decision making of the company. For example, if a negative feedback for a product or service of the store is posted on Twitter or Facebook, several customers will immediately follow and even distribute these comments. This could in time become a major issue which negatively effects future business.

(An example was the customer-generated YouTube posting, railing against United Airlines, when a customer had his guitar broken in transit -(Kietzman et al., 2011)). 
If a store manager can make a timely intervention then a potentially negative and damaging position can be transformed into a positive example of attentive customer service. A quick response will also attract many positive feeds from other social media users; ultimately it will increase the sales. Understanding the impact of social media can help today's businesses greatly. It is imperative for all businesses to include the social media in their daily operational plans to convert different segment of customers based on level of satisfaction and profitability into a star customer.

\subsection{Retail operations and sales promotion in the social media era}

The retail sector has gone through something of a sea-change over the last two decades. With the advent of the internet and social media, customers buying patterns started changing very drastically. This created a new wave of customer loyalty schemes to retain existing customers and also to attract new customers. Further to the introduction of loyalty schemes in the UK retail sector, the service industry encountered a pressing need to analyse customer data to enhance business benefits in terms of both creating sales and designing services. This analysis has helped to create a clear link between operational planning and marketing strategies (Ramanathan and Ramanathan, 2013). In the retail sector, sales promotions are normally analysed in relation to underlying factors of sales. The results of this analysis assist retail managers to plan production, logistics and distribution to make timely replenishment (Ramanathan, 2012). However, the quality of information in the supply chain makes the results of the analysis valid and useful for decision making (Forslund and Jonsson, 2007).

In this era of social media, any information from customers such as feedback about a product on sales and service quality, are made available to public quickly through different social media platforms such as Twitter, Facebook and store-based discussion forums. Customers will be very actively engaged in social media during a promotional deal in-store and online. At this time, it is crucial for mangers to maintain sufficient stock levels. Any stock-out will quickly create a huge dissatisfaction among potential buyers (Grant and Fernie, 2008). This dissatisfaction is often magnified in the 'glare' of social media, and is no longer confined to the stores. At these times a quick response or crisis-management approach is required by the operations managers to order and to replenish to secure sales; any failure to do this could also affect demand for non-promotional products. This scenario clearly outlines prevailing customers' buying behaviour in the social media era and highlights the importance of considered production planning and timely stock replenishment. 


\subsection{Impact of marketing in retail sales}

Retail shopping and repeat purchase behaviour remains a major focus for both researchers and practitioners (Grewal et al., 2004; Ramanathan, 2012). The purchasing behaviour of retail shoppers represents a complex mix of loyalty, repeat purchase and the propensity of a group of shoppers to purchase several brands in a category (Woodside and Walser, 2007).

There is agreement that loyal customers are important for the future of the business, and that this category is deserving of special attention. Since loyalty is a key to customer development and profitability, it is important to understand the loyalty condition in more detail, and to use this understanding to develop further the relationship with customers in the loyal category. Rowley (2005) identified four categories of loyalty as: captive, contented, convenience-seeker and committed and noted that any one individual is likely to exhibit the characteristics of each of these categories in relation to different products, services, outlets, and their associated brands.

Persistent brand loyalty emerges as an emotional bond created by trust, dialogue, frequency, ease of use and a sense of value and satisfaction, (Jenkinson, 1995; Ramanathan and Ramanathan 2013). However, researchers have suggested a range of conceptualisations defining loyalty; these range from repeat purchases to a lifetime relationship (Dick and Basu, 1994). A positive association between customer satisfaction and customer loyalty is often reported in previous research. Some studies suggest a strong association between customer satisfaction and behavioural intentions in certain country and industrial contexts, but not in the retail industry (Jani and Han, 2014). Customers and their responses to retail landscapes have attracted the attention of a number of studies including: Swinyard (1993) who proposed that consumer mood, involvement and the actual shopping experience interact and as a collective 'force' to significantly moderate consumers' shopping intentions. Especially in the presence of social media, customers' feedback will have a greater impact on shopping decisions of potential customers. This is further discussed in the following sections to conceptualise the idea of marketing effects specifically brand and promotional effect on customer satisfaction.

\section{Research hypotheses and Conceptual model}

Retail networks plan to offer unique experiences to customers by understanding their requirements and offering them a unique personalised service experience, through valuable feedback from customers (Chatterjee, 2013). Building loyalty and value is crucially important 
for retailers in the digital age. Loyalty is developed by maintaining a good relationship with customers, offering unique services and integrating operations and marketing functions thereby building on customer feedback.

Adding to the existing literature in both the marketing and operations fields, we discuss the role of social media reviews in relation to customer satisfaction. Further, we argue how customers' experiences and operational service quality contribute to the customer satisfaction. We also discuss the moderating role of promotional sales within this relationship. The conceptual model is shown in figure 1.

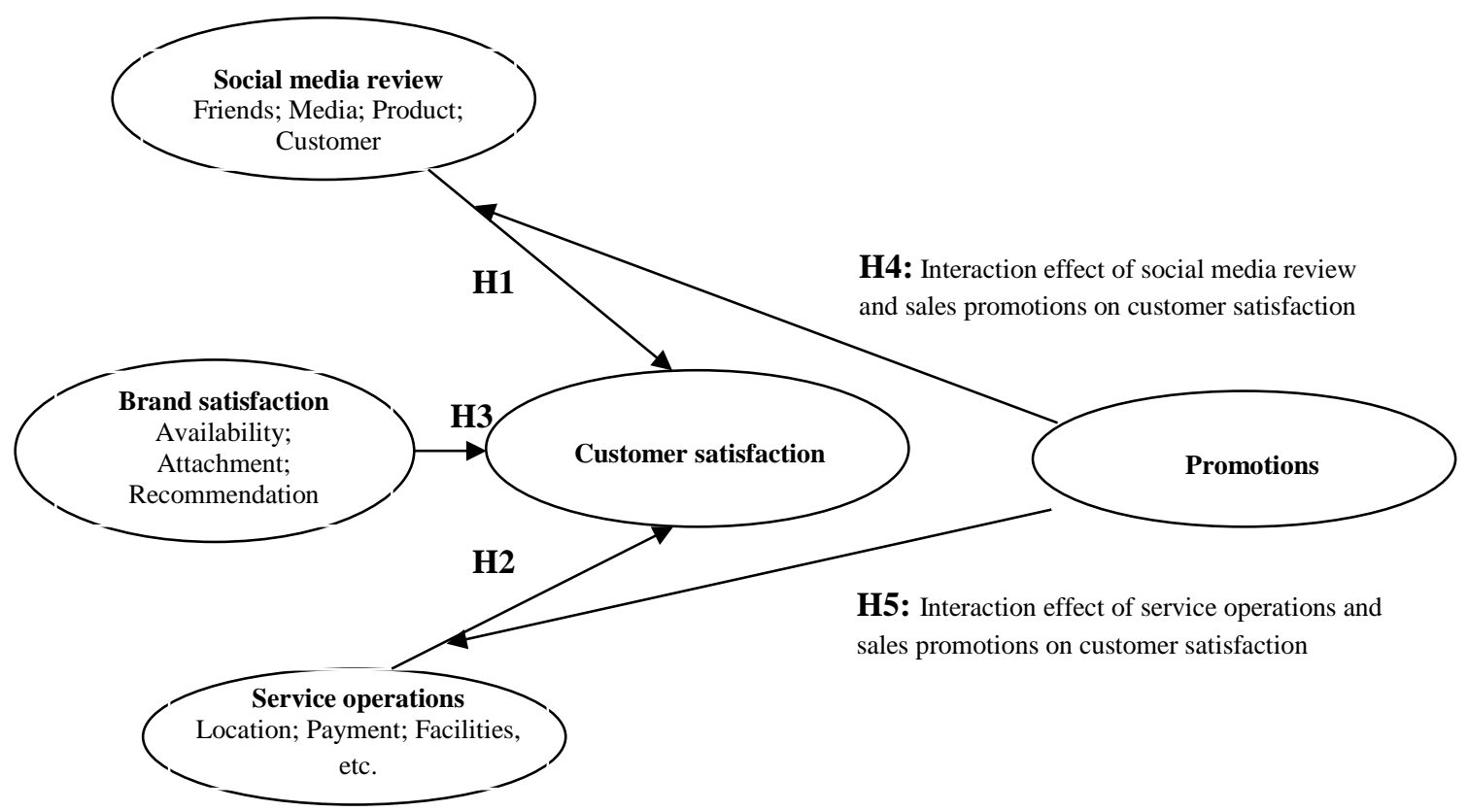

Figure1: Conceptual loyalty and value based retail business model in the era of social media

\subsection{Role of social media review and customer satisfaction}

The decisions of where to shop and what to buy are both influenced by reviews on products and those retail outlets selling those products. In retail purchases the consumer shopping decision making process (as featured in this research) is influenced by what they hear and see from the brand's messages and by opinions expressed by other peoples' (often latent) experience of the product, (Ind, 1997). Consumers are routinely bombarded by loyalty schemes and gift-vouchers. Consumers' brand knowledge may also be augmented by: objective reality (personal experience); constructed reality (messages from media sources) and experiences 
derived from other sources: social media and word-of-mouth (Antonides and Van Raaji, 1998; Sousa and Voss, 2009).

Although rational in intention, people differ in their perception of reality depending on their own experiences, life history and particular circumstances (schema). As a result of these factors, each individual forms a subjective view of reality (Antonides and Van Raaij, 1998, p.109).

Consumers garner information from friends and from reviews reported across several media channels, such information provides consumers with a basis to make decisions; often against a backdrop of time-poverty. Time pressure can significantly alter shopping behaviours of customers who are often stressed and have limited time to shop (Nicholls et al., 1997). Van Kenhove and De Wulf (2000) noted that high, as opposed to low time pressure may permit grouping consumers along this dimension.

Whereas Bagozzi et al., (1998) suggested that impulsive behaviour may moderate intentions to search and process information while food and grocery shopping. The pressurised consumer has been noted by several researchers, Kidwell and Jewell (2003) found when facing time pressure, consumer confidence in products and convenience play a major role in influencing purchase decisions. If a customer perceives the value of a good to be relatively high, the probability that they will make a purchase is likely to increase (Monroe, 1990; Zeithaml, 1988; Ramanathan and Ramanathan, 2013). Taken as an amalgam these factors can be considered to represent perceived value which can be considered as one of the most critical determinants of a consumer's shopping experience and ultimately: a consumer propensity to purchase (Chang and Wang, 2011; Ulaga and Chacour, 2001).

Decisions and preferences are formed over time and contribute to a shopper's satisfaction. Customer satisfaction is an attractive proposition to store owners' and their marketing agents. In this respect and since the 1980's, marketing organisations have invested time and money in understanding consumer behaviour: including wants, needs and desires. Researchers have acknowledged the importance of the affective and emotional aspects in consumer behaviour (Burk and Edell, 1989; Sousa and Voss, 2009).

Within the emotional realm, advertising has long been proclaimed as an important avenue by which marketers can make their offer tangible to customers (Grace and O' Cass, 2005). However, consumers are increasingly relying on word-of-mouth (WOM) communication in 
forming a positive attitude towards the brand (Swanson and Kelley, 2001). Research by Stafford and Day (1995) reported that communications adopting a rational or informational approach could reduce consumer uncertainty and increased the likelihood of future purchase intentions.

Further research by Cobb-Walgren et al. (1995) claimed that advertising could enhance perceived quality. However, the consumer's attitude or feelings towards the brand will ultimately influence their response, attitude and their level of satisfaction with the brand (Grace and O' Cass, 2005; Voss, 2003). Recent research from Keiningham et al. (2014) discussed the role of customer satisfaction and customer spending in current market where customer loyalty appears to be less prevalent.

Based on the above arguments we posit our first research hypothesis:

\section{H1: Social media reviews will have a direct impact on customer satisfaction}

\subsection{Role of service operations in customer satisfaction}

Retail organistaions seek to make their orgniastions attractive largely through managerially controllable decision-parameters such as site location, selling style, pricing and merchandise strategy, available parking or entertainment facilities, etc. (Berman and Evans, 2012). Other less controllable factors need to be considered including a customer's mood, local weather and even the economic situation. A customer's frame of mind can adversely effect their purchasing intentions, overall shopping experience and ultimately their level of shopping satisfaction.In order to be successful retailers need to be attractive, i.e. preferable or favourable, for their customers on every single stage of the buying process. Managers have to persuade consumers to come to their premises, make them stay and spend money as well as convince them to come again.

Bloemer and Odekerken-Schroder (2002) found such characteristics as: assortment of brands, atmosphere and location influenced the patronage of a particular supermarket and ultimately moderated that customer's perceived level of satisfaction. Store convenience has a major bearing on the shopping decision as consumers require a range of inter-linked services including: parking, flexible opening hours and convenient payment methods. A consumer's shopping experience is also affected by store attractiveness. Researchers feature the mediating effect of trust and commitment in the relationship between store attractiveness and store loyalty 
(Garbarino and Johnson 1999; Voss, 2003). That satisfaction in turn will have a positive impact on trust which in turn will have a positive impact on commitment (Ramanathan and Ramanthan, 2012).

Therefore, the concept of store attractiveness is broadened by taking into consideration any possible moderating effects that arise from the shopping experience and the consumer's involvement in the current shopping trip. This differential view leads to the distinction of situational-driven and sustainable (non-situational) aspects of store attractiveness with a direct or indirect impact on the consumer's behaviours and satisfaction. Accordingly, we posit our next research hypothesis as follows:

H2: Service operations will have positive impact on customer satisfaction

\subsection{Role of brand in customer satisfaction}

The nature of the constituent parts of a brand represents a multi-layered model of tangible and largely intangible elements. Functional features are augmented by associations, image, personality and identity, quality, value, symbolism, features, benefits and an array of service factors. Against this rich-tapestry consumers are required to make sense of these attributes to purchase and possibly re-purchase supermarket brands.

A key goal of marketing was to generate an intense bond between the consumer and the brand, and the main ingredient of this bond is trust (Hiscock, 2001; Ramanathan and Ramanathan, 2013). Powell (1990) views trust as cooperation that emerges from mutual interest. In-store promotions will further help potential buyers to buy brands by displaying the products in the right place. Consumer choice is increasingly becoming an emotionally-charged experience (Rosenbaum-Elliot and Percy, 2012). Keller (1998) outlined key determinants of consumer brand choice as memorability, meaningfulness and likability. These elements are instructive but prone to very high levels of interpretation and subjectivity.

Emotional attachment to brands is likely to be allied to favourable attitudes and these are reflected in strong attachments. Such attachments develop over time and are often based on the interactions between an individual and an attachment object (Baldwin et al., 1996; Thomson et al., 2005). However, interestingly a consumer could display a positive attitude towards a brand without having any experience with the brand. The number of objects / brands, consumers are emotionally attached to are generally few in number and are regarded as profound and significant (Ball and Tasaki, 1992; Richins, 1994; Thomson et al., 2005). 
Grimm (2005) investigated the relative importance and interaction effect within attitude components (i.e. cognitive, affective and conative-behaviour). An attitude was operationalised as: brand attitude perception, affective responses and conative as personality congruence. That brand attitudes were unique and were significant in relation to brand preferences with cognitive (rational) brand attibutes possessing the most influence in forming brand preference. Creating positive brand attitudes will help to induce the desired behavioural response towards their brand and increase satisfaction (Arora and Stoner, 1996; Zhu et al., 2011).

Moreover, attitudes themselves can exhibit temporal instability, as seemingly insignificant changes in context and means of elicitation through priming or framing manipulations lead to altered accessibility of concepts and moods and hence attitudes of varying valence (see: Cohen and Reed 2006). We can say that brands will exert a positive influence on customer satisfaction. Based on the above discussion we posit our next hypotheses as follows:

H3: Brand satisfaction will have a positive impact of customer satisfaction

\subsection{Moderating effects of sales promotions}

Kohli and Mahajan (1991) found that consumer price acceptance could be represented through individual utility profiling. Notwithstanding the well-documented price mechanism theory price levels are often associated with value, particularly in respect to the 'brand effect'. This relationship is itself closely allied to customer satisfaction. Fornell et al. (1996) related that the consequences of satisfaction is the increase of price sensitivity, brands with higher satisfaction levels are able to receive higher prices from customers. Price and pricing policies play an important role in influencing a consumer's shopping experience and greatly influences their purchasing decisions. Price promotions are endemic in fast moving (FMCG) markets. Abraham and Lodish (1987) reported that in many categories 90 percent of the volume sold was achieved via promotions. The short-term effect of such promotions is well-documented (Blattberg and Neslin, 1990).

Whether consumers perceptions would shift in the longer term has also attracted interest, In general food retailing is notoriously competitive with oligarchic completion observable in many territories. Davis et al. (1992) found that brand perceptions would not alter subsequent to price promotion; and postulated that consumers apparently did not recall the brands in question being promoted. However frequent promotions according to Lattin and Bucklin 
(1989) lowered consumer's preference prices for the brand resulting in lower sales volume at the regular price.

Consumers having made decisions to shop develop a range of experiences over time as they encounter a barrage of marketing and promotional activities. Within retail and notably foodretailing almost inevitably moves one irresistibly into the domain and paradigm of significant areas of promotion, place, price and product, i.e. the marketing mix: price, product, promotion and place (the 4 p's). These concepts have been updated to reflect the importance of the consumer decision making process and a 4 c's (Lauterborn, 1990), as opposed to a 4 p's model was proposed; where a consumer orientation superseded a manufacturer orientation.

Here, price becomes cost, product - choice, promotion - communication and place convenience. Cost/price element exemplifies the shift to a more-customer-focussed position as price acceptance represents the willingness of a consumer to purchase as a function of various price levels (Monroe, 1990).

Product pricing has been discussed widely in retail sector literature in the context of sales and affordability (Divakar et al., 2005; Ramanathan and Muyldermans, 2010). Some customers will buy the products during their shopping trips only if the product is on promotion or priced lower than normal. These shoppers are loyal to low-price than the brand. In such cases, the level of loyalty or retention rate of the customer is based on the promotions offered by the shop or brand. This supports the network model suggested by Chatterjee, 2013; that price level acts as an intervention in influencing purchase intention thereby affecting customer experience/satisfaction level. Ramanathan and Muydermans (2010) argued that identifying the underlying demand pattern for promotional sales can help planning and forecasting. But in the presence of social media, customers have more opportunities to check the price before buying. This potentially affects the whole experience and subsequently customer satisfaction changes considerably. If the promotional price is less than the expected price, the level of satisfaction may be higher, if not, then the level of satisfaction could reduce.

Based on the above argument we posit our next research hypotheses:

H4: Interaction of social media reviews and promotions will have a positive impact on customer satisfaction

H5: Interaction of service operations and promotions will have a positive impact on customer satisfaction 
All the above research hypotheses are represented in our conceptual model (see Figure 1).

\section{Methodology, data description and operationalization of research constructs}

Our study attempts to understand how retail networks leverage the potential of social media reviews in-line with the delivery of their unique service operations, to satisfy customers. To achieve this objective, we employed a suitable research approach namely, a paper-based customer survey that captured the true opinions of customers in a direct interaction maximising respondent participation (Voss, et al., 2002; Yin, 1994).

A retail customer purchase behaviour questionnaire on was distributed in the South East of England. This survey was paper-based and was conducted mainly outside the shopping mall and within communal social spaces. The survey was augmented by additional mail surveys to maximise responses. In total 102 usable responses were collected and analysed. We extended some help to respondents who physically required support, to complete the survey.

Non response-bias is not an issue in this case of face-to-face paper based survey. In this approach of data collection, we avoided item non-response bias by providing help to the respondents for filling the form and avoided unit non-response bias by approaching people who are willing to take part in the survey. These two approaches worked well to gain good responses.

For the lack of comparable statistics from non-responding firms, t-tests were used to test the response bias between early and late wave returned surveys, where late wave respondents were used as a proxy for non-respondents (Armstrong and Overton, 1977). In this study, 80 useable responses were received in the early wave and 22 in the late wave. The mean differences between the two groups with respect to the demographic data were tested using an unpaired ttest. No significant differences were observed at the 0.05 level, indicating no systematic bias between the two groups. These analyses indicate that the study has no non-response bias problems, and the final sample of 102 can be considered as representative of the population.

The survey questionnaire consisted of questions with respect to customer buying behaviour based on satisfaction in relation to social media review, marketing and service operations performance of retailers' as shown in Table 1. Some of the questions were directed towards brand satisfaction, pricing, review-related buying decisions, store attractions and store convenience. The last three questions were directed towards some general information on respondents. The collected data was analysed through SPSS for basic descriptive statistics. 
Also we used SPSS to check common-method bias using Harman's single factor method. The percentage of variance explained was less than 50 and hence proved that the common-method bias is not an issue for this data (Podsakoff et al., 2003). Then, to justify our proposed research framework a structural equation model (SEM) was developed using Smart Partial Least Squares (SPLS) version 3.2.0.

Operationalization of the research constructs has been made possible from the data we collected from the survey questionnaire. As our conceptual model is original and not based on any specific theory, we do not have sufficient social media theory supporting our conceptual model available from existing literature. In order to identify significant variables (or items) to be considered for data analysis, we conducted an exploratory factor analysis of items that are relevant to this model and considered the items with more than 0.4 loadings. This approach has evolved five factors with minimum of three items per factor. Then we conducted a confirmatory factor analysis (CFA) to confirm those items under each factor. Finally, we confirmed total of five factors, namely brand satisfaction, social media review, service operations, customer satisfaction and promotional sales. The construct 'brand satisfaction' consists of three measured items such as brand availability, customer attachment with the brand and their recommendation of the brand to friends and relatives. Items attached to other research constructs are listed in Table 1.

These confirmed factors have been proved distinct as none of the factors have correlation value closer to 1 . Significant correlation values are in the range $0.226-0.716$. This validates our data for discriminant validity. The confirmed factors and corresponding loadings are given in Table 1. Reliability of the data is confirmed by composite reliability as all values are above 0.785 (see Table 1).

Table 1: Confirmatory factor analysis and factor loadings

\begin{tabular}{|c|c|c|c|c|}
\hline Constructs & Measured items & Loadings & AVE & $\begin{array}{l}\text { Composite } \\
\text { reliability }\end{array}$ \\
\hline $\begin{array}{l}\text { 1.Brand- } \\
\text { satisfaction }\end{array}$ & $\begin{array}{l}\text { Brand availability } \\
\text { Brand attachment } \\
\text { Brand recommendation }\end{array}$ & $\begin{array}{l}0.767 \\
0.755 \\
0.934\end{array}$ & 0.670 & 0.861 \\
\hline $\begin{array}{l}\text { 2. Social media } \\
\text { review }\end{array}$ & $\begin{array}{l}\text { Introduced by friends } \\
\text { Reading product reviews } \\
\text { Introduced by media } \\
\text { Introduced by customer review }\end{array}$ & $\begin{array}{l}0.411 \\
0.402 \\
0.908 \\
0.945\end{array}$ & 0.397 & 0.785 \\
\hline $\begin{array}{l}\text { 3.Service } \\
\text { operations }\end{array}$ & $\begin{array}{l}\text { Easy to locate } \\
\text { Clear price tag } \\
\text { Clear display to choose } \\
\text { Availability of big brands }\end{array}$ & $\begin{array}{l}0.809 \\
0.810 \\
0.660 \\
0.735\end{array}$ & 0.487 & 0.911 \\
\hline
\end{tabular}




\begin{tabular}{|c|c|c|c|c|}
\hline & $\begin{array}{l}\text { Convenient parking } \\
\text { Convenient opening hours } \\
\text { Payment method } \\
\text { Low pricing } \\
\text { Money saving } \\
\text { Brand with cheap price } \\
\text { Non-essential items }\end{array}$ & $\begin{array}{l}0.485 \\
0.680 \\
0.710 \\
0.693 \\
0.662 \\
0.788 \\
0.577\end{array}$ & & \\
\hline 4.Satisfaction & $\begin{array}{l}\text { Q5 More choice } \\
\text { Q6 Availability of items } \\
\text { Q7 Store shopping satisfaction } \\
\text { Q8 Visit again } \\
\text { Q9 Recommend to friends }\end{array}$ & $\begin{array}{l}0.617 \\
0.551 \\
0.776 \\
0.639 \\
0.726\end{array}$ & 0.445 & 0.798 \\
\hline 5.Promotion sales & $\begin{array}{l}\text { Q39 Promotion -Branded } \\
\text { Q40 Promotion - price } \\
\text { Q41 Purchase - favourites } \\
\text { Q42 Purchase - Branded }\end{array}$ & $\begin{array}{l}0.892 \\
0.466 \\
0.941 \\
0.576\end{array}$ & 0.558 & 0.824 \\
\hline
\end{tabular}




\section{Results and discussions}

To check our proposed research model we use two-stage approach (Anderson and Gerbing, 1988; Sawhney, 2013). In the first stage, we construct the measurement model that relates to the measure items and corresponding constructs with latent constructs (see Figure 1 and Table 1).We use CFA and factor loading for this purpose as given in the section 4. In the second stage, we test our hypotheses by developing a structural equation model using PLS path models. This SEM model relates the endogenous and exogenous latent constructs through paths (Sawhney, 2013). Also in the second stage, we use moderators to test the influence of attractive promotions to customer satisfaction.

While developing the SEM we have identified that some of the path coefficients between the constructs are not as significant as anticipated. The brand satisfaction and interaction between promotion and social media review variables with customer satisfaction is not significant (see Figure 2). R-square of the construct 'customer satisfaction' is 0.748 . As per the loyalty and value based model social media review and service operations are positively related to customer satisfaction. This result gives a new insight into social media reviews which signals a strong association to customer satisfaction. Service operations positively influence customer satisfaction. Here, the path coefficient between 'service operations' and customer satisfaction is 0.430 , significant with $\mathrm{p}<0.05$. This result adds new dimensions to service operations as suggested by the previous findings of Ramanathan and Muyldermans, (2010) ; Divakar et al., (2005) that promotional sales with attractive displays and price reductions will significantly increase retail sales.

While both social media reviews and service operations are positively related to customer satisfaction, the path coefficient between brand satisfaction and customer satisfaction is not significant. This indicates a low level of retail brand importance in relation to customer satisfaction. Managers can make a note of this point that the promotion of branded products alone will not help to improve the retail network sales; rather it is important to ensure that the customer has a positive experience while shopping in-store. It indicates the importance of service operations and perceived quality in the retail outlet. 
Figure 2: Structural analysis without moderating effects

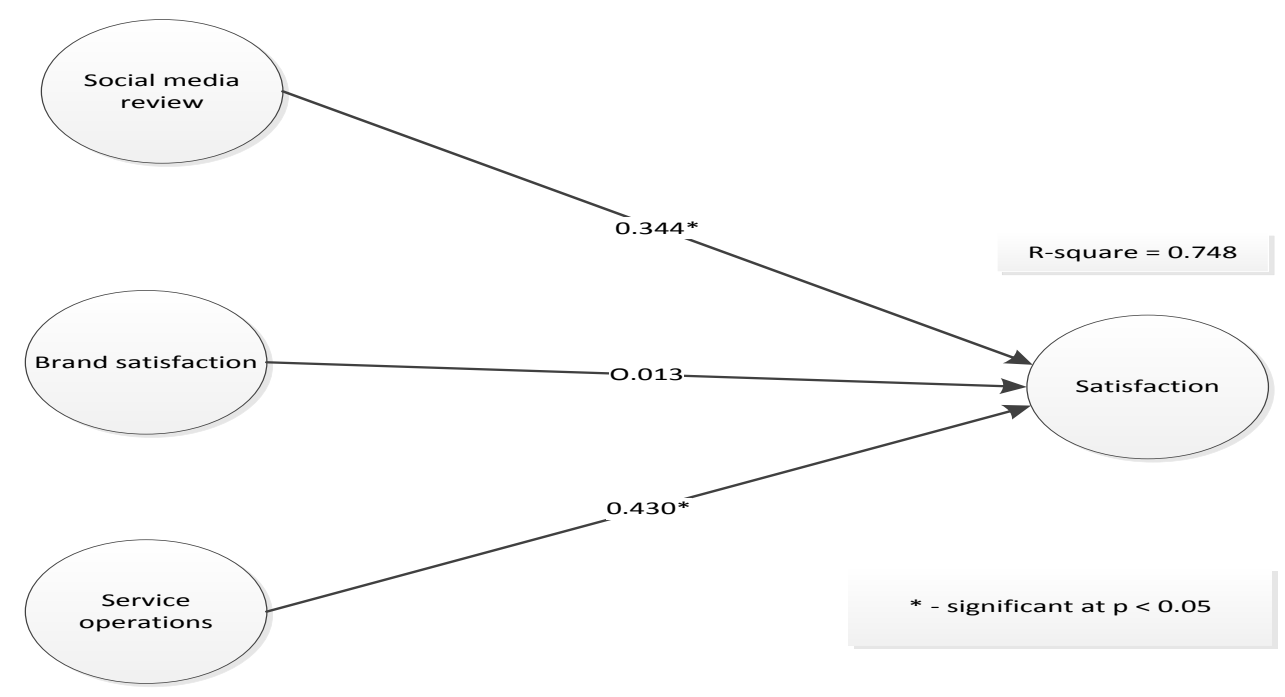

Figure 3: Complete structural model with moderating role of promotional sales

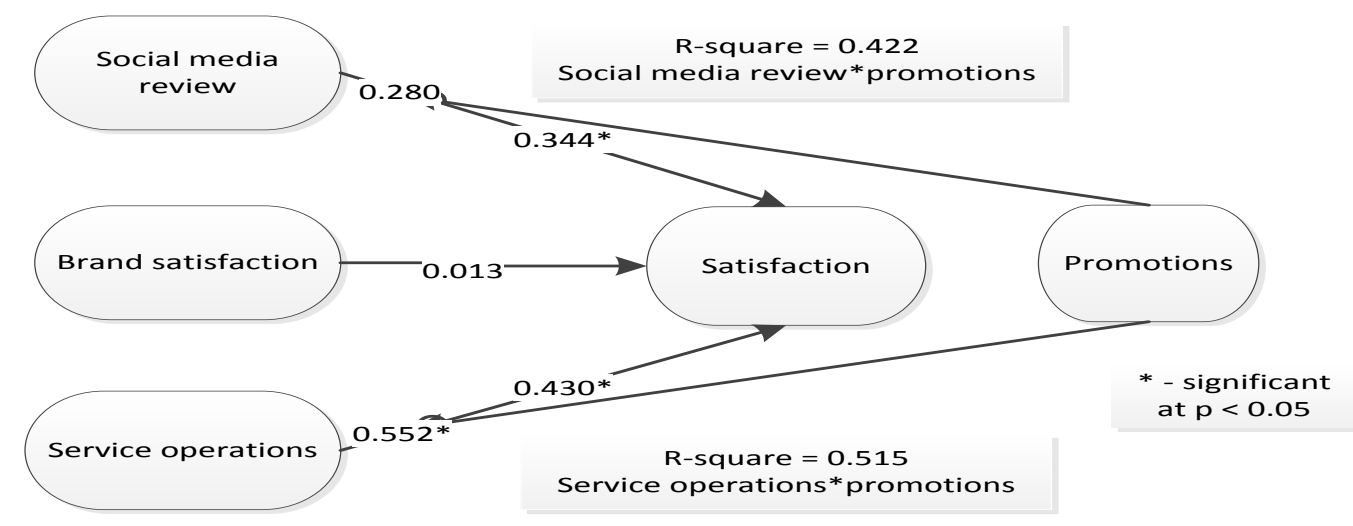

In stage 2 we test the moderating role of promotions in the above model. As given in Figure 3, promotional sales presented a significant interaction with social media reviews and service operations. The promotional sales proved to be a significant positive moderator of the relationship between service operations and customer satisfaction. But, the same has not been proved for the other link i.e. social media review and customer satisfaction. It indicates that the customers' pre-planned review will not change even when there are in-store sales promotions. 
Businesses can plan promotions in advance to reap the maximum benefit, with a special focus to escalate the level of customer satisfaction. We have also tested the moderating effect of age and income, but these did not show any significant effect to satisfaction.

Our results of hypotheses testing are given in the Table 2. Further to the above discussion it is clear from the statistical analysis that our hypothesised model of value based retail business model in the era of social media is valid. Most of the research hypotheses developed in Section 3 are valid except $\mathbf{H 3}$ and $\mathbf{H 4}$.

Brand satisfaction does not present a significant influence on customer satisfaction. Similarly social media reviews interaction with sales promotions does not influence customer satisfaction. As social media advocates, customers strongly rely on product and retail outlet reviews more than the sales promotions. Our analysis indicates retail outlets can leverage customer satisfaction combing unique service operations with promotions as well as paying careful attention towards social media reviews.

In the future, to gain advantages, retailers have to be in contact with the customer through Facebook and Twitter, to communicate with customer directly, answer complaints, thank customers for purchases and seek feedback about their experiences (Nair and Kamboj, 2014) instead of simply concentrating on promotions. Hence, it is responsibility of the operations manager of the retail outlet to make customer shopping interactions enjoyable improving nascent satisfaction levels, thereby increasing retail sales.

Non-support for the research hypothesis H3 (with p-value 0.622) represents that the Brand satisfaction is not part of customer satisfaction. As explained before, there is no moderation effect of sales promotion in the relationship between social media review and customer satisfaction.

We have calculated 'goodness of fit' criteria using the following formula (Tenenhaus et al., 2005)

$\mathrm{GoF}=\sqrt{\text { average }(\text { Communality }) \times \text { average }\left(R^{2}\right)}=\sqrt{0.701 \times 0.748}=0.724$, which is well within the suggested level Tenenhaus et al., 2005). 
Table 2: Structural path estimates

\begin{tabular}{|c|c|c|}
\hline Research hypotheses (determinants) & $\begin{array}{l}\text { Estimates (t-value; } \\
\text { p-value) }\end{array}$ & $\begin{array}{l}\text { Supported } \\
\text { or not supported }\end{array}$ \\
\hline $\begin{array}{l}\text { H1: Shop review will have a positive impact on customer } \\
\text { satisfaction }\end{array}$ & $0.344(2.412 ; 0.016)$ & Supported \\
\hline $\begin{array}{l}\text { H2: Service operations will have positive impact on customer } \\
\text { satisfaction }\end{array}$ & $0.430(2.785 ; 0.006)$ & Supported \\
\hline $\begin{array}{l}\text { H3: Brand satisfaction will have a positive impact on customer } \\
\text { satisfaction }\end{array}$ & $0.013(0.494 ; 0.622)$ & Not Supported \\
\hline $\begin{array}{l}\text { H4: Interaction of social media review and promotion will have } \\
\text { a positive impact on customer satisfaction }\end{array}$ & $0.280(1.593 ; 0.112)$ & Not supported \\
\hline $\begin{array}{l}\text { H5: Interaction of service operations and promotion will have a } \\
\text { positive impact on customer satisfaction }\end{array}$ & $0.552(3.110 ; 0.002)$ & Supported \\
\hline
\end{tabular}

Table 2 summarises the hypothesis testing and results. It is clear from these results and also from the above discussions that brand satisfaction does not directly impact on customer satisfaction. There are other factors such as shop reviews and the level of service provided to shoppers influence the customers positively. At the same time, it is interesting to note that although shop reviews have a positive impact on customer satisfaction, the interaction effect of these reviews and promotions do not influence customer satisfaction.

However, the interaction effect of service operations and promotions together do have a positive impact on customer satisfaction. This point highlights the importance of service operations while retail networks are running promotions. These results clearly indicate that retail sector cannot survive just by responding to social media reviews, they also need to focus on localising service operations to deliver a good quality service to those customers shopping in-store.

Customer satisfaction is the key for retail business successes. Poorly managed services can lead to dissatisfied customers that could ultimately lead to financial failure (Keiningham et al., 2014). Keiningham et al. (2014) also proposes that misguided attempts to improve customer satisfaction can affect the company's financial position. Recent failures at Tesco in the UK is one of the worst examples of misguided or poor judgemental decision making. Our research model in this paper, discusses the significant impact of social media reviews and service operations on customer satisfaction. It also highlights that social media reviews in the presence 
of promotions are not instrumental in achieving customer satisfaction. However, without good services provision, promotions will not be successful in creating positive customer satisfaction.

\section{Conclusions and future research}

Social media has undoubtedly changed the way of doing business in the last two decades. It has not only changed the competitive landscape, but provided greater choices and options for customers providing tangible examples of the provision of both the convenience and choice concepts discussed in the 4c's model (Lauterborn, 1990). Subsequently this new evolution of social media and customer reviews has become instrumental in increasing the efficiency of supply chain related operations. Recent research by Munar and Jacobsen (2014) insists that Big data and social media will have a greater mediating role in the success of businesses by an increasing dissemination of experience and feelings. This is very much evident from many businesses of $21^{\text {st }}$ century, especially at fashion retailers (Nair and Kamboj, 2014).

As Keiningham et al. (2014) found, it is difficult to measure the exact link between customer satisfaction and buying behaviour. However, it is somewhat more manageable to assess customer loyalty levels for the store and branded goods. Increased customer service levels are required to differentiate stores in the battle to gain or retain market share in this sector. By making favourite brands available to customers at the right time and in the right place will help retailers to win the hearts and minds of their customers. At the same time, it is also important in this era of electronic communication to maintain favourable customer ratings for your product and store. In order to do this, every business needs to focus on methods to convert opportunistic buyers (who buy only during promotional sales) to regular and loyal buyers. This involves a broader understanding of the market needs and a flexible sales strategy. Ultimately, the price paid to obtain customer satisfaction is high (Keiningham et al., 2014).

Our research is based on previous literature on service quality and customer satisfaction. We also added a new factor - the impact of customer reviews (social media). It is important to note that customer satisfaction has many underlying factors such as promotions, loyalty schemes, service quality and branded items etc. A recent article from MIT Management Sloan (Keiningham et al., 2014) stated that "the relationship between customer satisfaction and customer spending behaviour is very weak". Hence it is important to understand what exactly helps businesses to gain customer satisfaction. Social media continues to play an important 
role in influencing customer shopping decisions. And therefore, discussing these factors are necessary to develop the research framework incorporating social media impact; to enable store managers to create a new approach of service, while planning relevant in-store promotions.

Our study developed a loyalty and value based network model and we validated the model using the empirical data from UK retail sector, mainly grocery shopping. Weekly shopping is quite a normal practice of UK population, especially for families with young children. This practice has not been completely replaced by online shopping. Hence, it becomes mandatory for store managers to improve the quality of the services in-store to improve customer satisfaction, as this will be translated into good customer reviews and increased store visits.

Our model is original and the first of its kind to integrate operations, marketing and feedback through social media review. For retailers our study suggests how to create value and loyalty in the network using social media review in the digital era. Our findings suggest that social media reviews and unique service operations represent a significant influence on customer satisfaction. When compared to social media reviews and unique service operations, brand satisfaction doesn't appear to really influence customer satisfaction levels.

However, sales promotion increases customer satisfaction when it interacts with service operations but, sales promotion does not appear to have a strong effect within social media reviews. Our study signals that, retail outlets have to be in direct contact with customers through social media by attending to their complaints and appreciating their support rather than slavishly over-focussing on sales promotions.

Within an increasingly influential social media landscape coupled with the development of big data, many retailers around the globe exist in a state of confusion in making clear choices between marketing and operations. Analysis of our research model clearly states that the retail success will not be guaranteed if service operations are compromised. Planning sales promotions with good service provision can help retailers to obtain positive social media reviews from customers. This can help the company to maintain its competitive market position. 
Our research is based on UK retail customer response from one part of the UK. It will be useful if this research can be extended for other parts of the UK in various other service sectors. Our study specifically focussed on social media reviews and in future, researchers can consider other aspects of using big data related to social advertisements, social and interest graphs, social sharing and production innovation. It will also be interesting to consider other web applications used for shopping, such as virtual personal shopping, in future research on retail customer satisfaction and service quality expectations. Similarly, we considered only customer satisfaction as main outcome; future research can also consider other outcomes such as decrease product return rate, increase online sales and increase average order value.

\section{References}

Abraham, M.M. and Lodish, L.M. (1987), "Promoter: An automated promotion evaluation system", Marketing Science, Vol. 6 No. 2, pp. 101-23.

Anderson, J.C. and Gerbing, D.W. (1988), "Structural equation modeling in practice: A review and recommended two-step approach”, Psychological Bulletin, Vol. 103 No. 3, pp. 411-423.

Antonides, G. and Van Raaij, F.W. (1998), Consumer Behaviour: A European Perspective, Wiley, London.

Armstrong, J.S. and Overton, T.S. (1977), "Estimating Nonresponse Bias in Mail Surveys", Journal of Marketing Research, Vol. 14 No. 3, pp. 396-402.

Arora, R. and Stoner, C. (1996), "The effect of perceived service quality and name familiarity on the service selection decision", Journal of Services Marketing, Vol. 10 No. 1, pp. 22-34.

Bagozzi, R.P., Rosa, J.A., Celly, K.S. and Coronal, F.C. (1998), Marketing Management, Prentice-Hall, Englewood Cliffs, NJ.

Baldwin, M. W., Keelan, J. P. R., Fehr, B., Enns, V., \&Koh-Rangarajoo, E. (1996), “Social-cognitive conceptualization of attachment working models: Availability and accessibility effects", Journal of Personality and Social Psychology, Vol. 71 No.1, pp. 94-109.

Ball, A. D. and Tasaki, L. H. (1992), "The role and measurement of attachment in consumer behaviour", Journal of Consumer Psychology, Vol. 1 No.2, pp. 155-172.

Blattberg, R.C. and Neslin, S.A. (1990), Sales Promotion - Concepts, Methods and Strategies, Prentice-Hall, Inc., Englewood Cliffs, NJ.

Bloemer, J.M.M., Odekerken-Schroder, G., (2002), "Store Satisfaction and Store Loyalty Explained By Customerand Store-Related Factors", Journal of Consumer Satisfaction, Dissatisfaction and Complaining Behaviour, Vol. 15, pp. 68-80.

Berman, B. and Evans, J.R. (2012). Retail Management: A strategic approach. Pearson International Edition 12 e.

Burk, M.C. and Edell, J.A. (1989), "The impact of feelings on ad-based affect and cognition", Journal of Marketing Research, Vol. 26 No. 1, pp. 69-83.

Chang, H.H. and Wang, H.W. (2011), "The moderating effect of customer perceived value on online shopping behaviour", Online Information Review, Vol. 35 No. 3, pp. 333-359.

Chatterjee, S. (2013).Simple rules for designing business models. California Management Review, 55 (2), 97 124.

Cobb-Walgren, C., Ruble, C. and Donthu, N. (1995), "Brand equity, brand preference, and purchase intent", Journal of Advertising, Vol. XXIV No. 3, pp. 25-40.

Cohen, J.B and Reed, A. (2006). A Multiple Pathway Anchoring and Adjustment (MPAA) Model of Attitude Generation and Recruitment. Journal of Customer Research, Vol. 33 No.1, pp 1-15.

Danese, P. (2007), "Designing CPFR collaborations: insights from seven case studies", International Journal of Operations \& Production Management, Vol. 27 No. 2, pp. 181-204. 
Divakar, S., Ratchford, B.T., Shankar, V., (2005), CHAN4CAST: a multichannel, multi- region sales forecasting model and decision support system for consumer packaged goods. Marketing Science Vol. 24 No.3, 334350.

Davis, S., Inman, J.J. and McAllister, L. (1992), "Promotion has a negative effect on brand evaluations - or does it? Additional disconfirming evidence", Journal of Marketing Research, Vol. 29 No.1, pp. 143-8.

Dick, A. and Basu, K. (1994), "Customer loyalty: toward an integrated conceptual framework", Journal of Marketing Science, Vol. 22, No. 2, pp. 99-113.

Fernie, J (1995), "International comparisons of supply chain management in grocery retailing”, The Services Industry Journal, Vol. 15, No. 4, pp. 134-147.

Fornell, C., Johnson, M.D., Anderson, E.W., Cha, J. and Bryant, B.E. (1996), “'The American customer satisfaction index nature, purpose, and findings", Journal of Marketing, Vol. 60 No.4, October, pp. 7-18.

Forslund, H. and Jonsson, P. (2007), "The impact of forecast information quality on supply chain performance", International Journal of Operations \& Production Management, Vol. 27 No.1, pp. 90-107.

Garbarino, E. and Johnson, M.S. (1999), "The different roles of satisfaction, trust, and commitment in customer relationships", Journal of Marketing, Vol. 63 No. 2, pp. 70-87.

Grace, D. and O' Cass, A., (2005), "Examining the effects of service brand communications on brand evaluation", Journal of Product \& Brand Management, Vol. 14 No. 2, pp.106 - 116.

Grant, D.B. and Fernie, J. (2008) "Research note: Exploring out-of-stock and on-shelf availability in non-grocery, high street retailing", International Journal of Retail \& Distribution Management, Vol. 36, No. 8, pp. 661 - 672.

Grewal, Dhruv, Levy, Michael, \& Lehmann, Donald. (2004), "Retail branding and loyalty: An overview". Journal of Retailing, Vol. 80, No.4, pp. 9-12.

Grimm, P.E. (2005), “A components' impact on brand preference”, Journal of Business Research, Vol. 58 No. 4, pp. 508-17.

Hiscock. J. 2001. Most Trusted Brands, Marketing, March, 32-33, cited in Elliot, R. and Yannopoulou. 2007. The Nature of Trust in Brands: A Psychosocial Model, European Journal of Marketing, Vol. 41 No. 9/10, pp. 988998.

Ind, N. (1997), The Corporate Brand, Macmillan Press Ltd. London.

Jani, D. and Han, H. (2014). "Personality, satisfaction, image, ambience, and loyalty: Testing their relationships in hotel industry". International Journal of Hospitality Management, Vol. 37, pp. 11-20.

Jenkinson, A. (1995), "Retailing and shopping on the internet", International Journal of Retail \& Distribution Management, Vol. 24 No. 3, pp. 26-37.

Keiningham, T. Gupta, S. Aksoy, L., and Buoye, A., (2014), “The high price of customer satisfaction”, MIT Sloan, Management Review, Vol. 55 No. 3, pp. $36-46$.

Keller, K.L. (1998), “Strategic Brand Management: Building, Measuring, and Managing Brand Equity”, Prentice-Hall International, Hemel Hempstead.

Kidwell, B. and Jewell, R.D. (2003), "An examination of perceived behavioural control: Internal and external influences on intention", Journal of Psychology and Marketing, Vol. 20 No.7, pp. 625-642.

Kietzmann, J.H., Hermkens, K., McCarthy, I.P. and Silvestre, B.S. (2011), "Social Media? Get serious! Understanding the functional building blocks of social media", Business Horizons, Vol. 54 No. 3, pp. 241-251.

Kohli, R. and Mahajan, V. (1991), "A Reservation Price Model for Optimal Pricing of Multiattribute Products in Conjoint Analysis", Journal of Marketing Research, Vol. 28 No. 3, pp. 347-354.

Kopalle, P.K. and Neslin, S.A. (2003), "The Economic Viability of Frequent Reward Programs in a Strategic Competitive Environment," Review of Marketing Science, Vol.1 No. 1, pp. 1-39.

Lattin, J.M. and Bucklin, R.E. (1989), "Reference effects of price and promotion on brand choice behavior", Journal of Marketing Research, Vol. 26, No. 3, pp. 299-310.

Lauterborn, B. (1990). New Marketing Litany: Four Ps Passé: C-Words Take Over. Advertising Age, 61(41), 26.

Martenson, R. (2007) "Corporate brand image, satisfaction and store loyalty: A study of the store as a brand, store brands and manufacturer brands", International Journal of Retail \& Distribution Management, Vol. 35 No. 7 , pp. $544-555$.

Matzler, K., Pechlaner, H., Abfalter, D., \& Wolf, M. (2005).Determinants of response to customer e-mail enquiries to hotels: evidence from Austria. Tourism Management, Vol. 26 No. 2, pp. 249-259.

Monroe, K.B. (1990), Pricing, 2nd ed., McGraw-Hill, New York, NY.

Munar, A.M., Jacobsen, J.K.S., (2014). Motivations for sharing tourism experiences through social media. Tourism Management, Vol. 43, pp. 46-54.

Nair, S. and Kamboj, D. (2014), "Social media in the retail industry", Infosys Labs Briefings, Vol. 12 No.1, pp. 74-81.

Nicholls, J., Roslow, S. and Dublish, S. (1997), "Time and companionship: key factors in Hispanic shopping behavior”, Journal of Consumer Marketing, Vol. 14 No. 3, pp. 194-205. 
Podsakoff, P.M., MacKenzie, S.B., Lee, J.Y., \& Podsakoff, N.P. (2003), “Common method Biases in behavioral research: a critical review of the literature and recommended Remedies", Journal of Applied Psychology, Vol. 88 No. 5, pp. 879-903.

Powell, W.M. (1990), "Neither Market or Hierarchy: Network Forms of Organization”, Research in Organizational Behaviour, Vol. 12, pp. 295-336.

Ramanathan, U and Muyldermans, L (2010), Identifying demand factors for promotional planning and forecasting: A case of a soft drink company in the UK, International Journal of Production Economics Vol. 128 No. 2 pp. 538545.

Ramanathan, U and Ramakrishnan, R (2011), Guests' perceptions of factors influencing customer loyalty: An analysis for UK hotels, International Journal of Contemporary Hospitality Management, Vol. 23 No 1, pp. 7-25.

Ramanathan, R., George, J. and Ramanathan, U. (2013). The role of logistics in e-commerce transactions: An exploratory study of customer feedback and risk, Springer, UK.

Ramanathan, U., (2012). Supply chain collaboration for improved forecast accuracy of promotional sales. International Journal of Operations \& Production Management, Vol. 32 No. 6, pp. 676-695.

Ramanathan, U. and Ramanathan, R. (2013), "Investigating the impact of resource capabilities on customer loyalty: A structural equation approach for the UK hotels using online ratings", Journal of Services Marketing, Vol. 27 No.5, pp 404-415.

http://www.retailingtoday.com/article/study-81-research-online-making-big-purchases, accessed $9^{\text {th }}$ March, 2015.

Richins, M. L. (1994), "Special possessions and the expression of material values". Journal of Consumer Research, Vol. 21 No. 3, pp. 522-533.

Rosenbaum- Elliott, R. and Percy, L. (2012), Strategic Advertising Management. 4th. edn. Oxford University Press.

Rowley, J. (2005), "Building brand webs Customer relationship management through the Tesco Clubcard loyalty scheme", International Journal of Retail \&Distribution Management Vol. 33, No. 3, 2005, pp. 194-206.

Sawhney, R. (2013). Implementing labor flexibility: A missing link between acquired labor flexibility and plant performance. Journal of Operations Management, Vol. 31 No.1-2, pp. 98-108.

Stafford, M.R. and Day, E. (1995), "Retail services advertising: the effects of appeal, medium, and service", Journal of Advertising, Vol. 24 No.1, pp 57-71.

Sousa, R. and Voss, C.A., (2009). "The effects of service failures and recovery on customer loyalty in e-services An empirical investigation”. International Journal of Operations \& Production Management, Vol. 29 No. 8, pp. 834864.

Swanson, S.R. and Kelley, S.W. (2001), "Service recovery attributions and word-of-mouth intentions", European Journal of Marketing, Vol. 35 No. 1/2, pp. 194-211.

Swinyard, William R. (1993), "The Effects of Mood, Involvement, and Quality of Store Experience on Shopping Intentions", Journal of Consumer Psychology, MIT Press, Cambridge, MA., Vol. 20, September, pp. 271-280.

Tenenhaus, M., Vinzi, V.E., Chatelin, Y-M, Laurence. (2005), "PLS path modelling”, Computational Statistics \& Data Analysis, Vol. 48 No.1, pp. 159 - 205.

Thomson, M. MacInnis, D. and Park, W. (2005), "The Ties That Bind: Measuring the Strength of Consumers' Emotional Attachments to Brands", Journal of Consumer Psychology, Vol. 15 No. 1, pp. 77-91.

Ulaga, W. and Chacour, S. (2001), "Measuring customer perceived value in business markets", Industrial Marketing Management, Vol. 30 No. 6, pp. 525-540.

Voss, C.A. (2003), "Rethinking paradigms of service", International Journal of Operations \& Production Management, Vol. 23 No. 1, pp. 88 - 104.

Voss. C., Tsikriktsis, N. and Frohlich, M. (2002). "Case research in Operations Management”, International Journal of Operations and Production Management, Vol. 22 No. 2, pp. 195-219.

Woodside, A.G and Walser, M.G, (2007), "Building strong brands in retailing", Journal of Business Research, Vol. 60 No. 1, pp. 1-10.

Xiang, Z and Gretzel, U., (2010). Role of Social media in online travel information search. Tourism Management, Vol. 31 No.2, pp. 179-188.

Yin, R.K. (1994). "Case study research Design and Methods Applied Social Research Methods Series”, Vol. 5 (2nd Edition) Sage Publications, London.

Zeithaml, V.A. (1988), "Consumer perceptions of price, quality, and value: a means-end model and synthesis of evidence", Journal of Marketing, Vol. 52, July, pp. 2-22.

Zhu, J. C., Ramanathan, R. and Ramanathan, U. (2011), "Measuring Service Quality using SERVQUAL and AHP: An Application to a Chinese IT Company and Comparison", International Journal of Services and Operations Management, Vol. 8 No.4, pp. 418-432. 